\title{
Study of Government's Strategy on Clean Water Availability in Indonesia
}

\author{
Mohammad Taufik ${ }^{1}$, Etika Khairina ${ }^{2 *}$, Roma Hidayat ${ }^{3}$, Rita Kalalinggi ${ }^{4}$ Mochammad Iqbal \\ Fadhlurrohman ${ }^{5}$ \\ ${ }^{1}$ Department Of Government, Faculty Social and Politic, University Mulawarman, Samarinda 75119, Indonesia \\ ${ }^{2}$ Department Of Social Humanities, Universitas Putera Batam. Jalan R. Soeprapto, Muka Kuning, Batam 29452, Indonesia \\ ${ }^{3}$ Physics Study Program, Faculty of Mathematics and Natural Sciences, Universitas Andalas Padang, Indonesia \\ ${ }^{4}$ Government Science, Faculty of Social and Politic, Universitas Mulawarman, Indonesia \\ ${ }^{5}$ E-Governance and Sustainability Institute ESI, Yogyakarta, Indonesia \\ *Corresponding author: etikakhairina@gmail.com
}

Info Artikel:Diterima 2 Desember 2021 ; Direvisi 26 Januari 2022 ; Disetujui 3 Februari 2022

Tersedia online : 25 Februari 2022 ; Diterbitkan secara teratur : Februari 2022

Cara sitasi (Vancouver): Taufik M, Khairina E, Hidayat R, Kalalinggi R, Fadhlurrohman MI. Study of Government's Strategy on Clean Water Availability in Indonesia. Jurnal Kesehatan Lingkungan Indonesia [Online]. 2022 Feb;21(1):111121. https://doi.org/10.14710/jkli.21.1.111-121.

\begin{abstract}
ABSTRAK
Latar belakang: Tujuan tulisan ini adalah mengkaji dan menganalisis strategi pemerintah dalam menjaga dan mengelola sumber daya air dalam mencapai ketersediaan air bersih di Indonesia, mengingat peristiwa perubahan iklim juga dapat meningkatkan krisis air. Pemanfaatan air secara terus menerus dan terbatasnya jumlah air yang dapat dieksplorasi dan dikonsumsi dipengaruhi oleh jumlah penduduk yang menyebabkan meningkatnya kebutuhan air. Tulisan ini meninjau secara filosofis dan konseptual yang akan menggabungkan perspektif dari langkah-langkah praktis di tingkat dasar seperti strategi perlindungan berupa kebijakan yang telah dibuat seperti Regulasi, Pengelolaan (dalam pengelolaan akan dikaji sejauh mana campur tangan manusia/pemerintah dalam menjaga kesehatan Ekosistem Lingkungan, termasuk sumber air dan sejauh mana pemanfaatannya, kemudian metode apa yang dipakai dan disepakati oleh pemangku kepentingan dalam memastikan kebutuhan air sehingga dapat terpenuhi), evaluasi dan usaha menjaga/melindungi sumber air.

Metode: Metode penelitian ini menggunakan analisis kualitatif dengan pengumpulan data yang dilakukan melalui studi pustaka dengan mengumpulkan berbagai bahan dari buku, jurnal, hasil penelitian, dan media (berita) yang kemudian dianalisis menggunakan model triangulasi yang terdiri dari reduksi data, penyajian data, dan penarikan kesimpulan.

Hasil: Pada pelaksanaannya, pemerintah telah melakukan pengelolaan ketersediaan air secara kuantitatif dan kualitatif dengan memperhatikan dan menentukan program prioritas dan kegiatan dalam pemanfaatan air. Hal tersebut dilakukan dengan pemantauan air sungai secara manual dan otomatis secara kontinu. Upaya selanjutnya dalam pengelolaan ialah pelaksanaan konservasi air, perlindungan pelaksanaan pengelolaan secara teknis dan nonteknis berupa kebijakan dalam pengelolaan sumber daya air seperti yang telah diatur dalam Undang-Undang No. 17 Tahun 2019 tentang Sumber daya air. Undang-undang ini memuat kebijakan yang secara tegas mengatur tentang sumber air di Indonesia, termasuk evaluasi berupa upaya pengendalian yang didasarkan dari hasil suatu penilaian bahaya dan risiko terhadap air tanah (Groundwater Hazard and Risk Assessment).

Simpulan: Secara konsep, strategi yang dupayakan telah mengarah pada terbebasnya Indonesia dari krisis air di masa sekarang dan masa mendatang sesuai dengan perlindungan/produk yang mengatur. Namun pada Pelaksanaan Pengelolaan, konservasi dilakukan secara parsial atau sebagian. Pengelolaan air tanah belum dilaksanakan secara arif dan komprehensif. Tidak adanya pendekatan yang berkelanjutan dan perubahan paradigma oleh pihak yang terlibat dalam pengelolaan ketersediaan air menjadi pemicu tidak terjalinnya koordinasi yang baik antar pemangku kepentingan. Penilaian risiko belum begitu signifikan karena tidak ada
\end{abstract}


unsur kontinuitas dalam pelaksanaan pengelolaan dan pemanfaatan, baik oleh masyarakat maupun kebijakan yang mengatur.

Kata kunci: Pemerintah; Pengelolaan; Ketersediaan Air.

\begin{abstract}
Background: This paper aims to examine and analyze the government's strategy in maintaining and managing water resources in ensuring clean water availability in Indonesia, considering that climate change can also increase the water crisis. The continuous use of water and the limited amount of water that can be explored and consumed is influenced by the population, which causes an increase in water demand. This paper reviews philosophically and conceptually by combining the perspectives of practical steps at the basic level such as protection strategies in the form of policies that have been made such as regulation, management (in management, the extent of human/government intervention in maintaining the health of environmental ecosystems, including water sources and the extent to which they are used, then what methods are used and agreed upon by stakeholders in ensuring that water needs can be met), evaluation, and efforts to maintain/protect water sources.
\end{abstract}

Methods: The research method used qualitative analysis with data collection carried out through library research by collecting various materials from books, journals, research results, and media (news). The data were then analyzed using a triangulation model consisting of data reduction, data presentation, and conclusion.

Results: In practice, the government has carried out quantitative and qualitative management of water availability by considering and determining priority programs and activities in water utilization. This is done by monitoring river water manually and automatically continuously. The next effort in management is the implementation of water conservation, protection of the implementation of technical and non-technical management in the form of policies in the management of water resources as regulated in Law No. 17 of 2019 concerning Water Resources. This law contains policies that strictly regulate water resources in Indonesia, including evaluation of control measures based on the results of an assessment of hazards and risks to groundwater (Groundwater Hazard and Risk Assessment).

Conclusion: Conceptually, the strategy sought has led to Indonesia's freedom from water crises in the present and the future by the protection/products that regulate it. Still, it is carried out partially in the implementation of conservation management. Groundwater management has not been implemented wisely and comprehensively, and there is no appropriate approach. Then the paradigm shift by the parties involved in water availability is the trigger for the lack of good coordination between stakeholders. The risk assessment is not highly significant because there is no element of continuity in implementing management and utilization by both the community and the policies that regulate it.

Keywords: Government;Management; Water Availability.

\section{INTRODUCTION}

One of the resources with a crucial function for the survival of living beings on Earth is water. Some activities and life processes cannot take place in the absence of water, making the availability of water a major concern and priority ${ }^{(1)}$. In its development and process of life, human activities that continue without considering an environmental perspective lead water supplies to decline. Moreover, the nature of water, which has relatively no substitute sources, will become a problem if its utilization is not considered. Indonesia is the fifth country in the world with the most water sources. Indonesia is known for having natural resource potential, especially in the maritime sector ${ }^{(2)}$. Indonesia is also an archipelagic country with 17,499 islands, an 81,000 km coastline, and an area of waterways consisting of territorial, archipelagic, and inland waters totaling an area of 2.7 million $\mathrm{km}$, or $70 \%$ of the Republic of Indonesia's total territory. Indonesia also has an Exclusive Economic Zone (EEZ) that covers $3.1 \mathrm{~km}^{2}$, bringing the total area of the Indonesian Sea to 5.8 million $\mathrm{km}$. The sea is a source of water that flows into rivers, which are heavily used by the people for daily needs. The potential of Indonesia's natural resources can help to maintain the availability of clean water in the country ${ }^{(3)}$.

Based on these data, Indonesia is one of the countries with abundant water resources and natural resource potential. However, in its use, there are fundamental issues that arise in the community. The phenomena that are currently being faced by the community are seasonal variations and spatial inequality of water supplies. During the rainy season, several areas in Indonesia receive an abundance of water which causes flooding and other disasters ${ }^{(4)}$. On the other hand, in the dry season, water shortages and droughts occur in other areas. The next fundamental problem is the limited amount of water that can be explored and consumed which is affected by the number of residents, causing an increase in the demand for raw water. The need for water thus 
skyrocketed during the COVID-19 pandemic. Data from IWI (Indonesia Water Institute) found that changes in clean water usage patterns during the pandemic increased 2 to 3 times compared to normal conditions (before the pandemic). During the COVID19 pandemic, $18 \%$ of the Indonesian population washed their hands more than 10 times per day. IWI also discovered that $27 \%$ of the public bathed more than 3 times a day, making the water demands rise drastically to $73 \%$ during the COVID-19 pandemic. The problem of clean water supply is increasingly limited to the alternative water sources that can be utilized by the community. As a result, this implies that water reserves in Indonesia are indeed large, but it depends on the government's attention as a decision-maker and the party in charge of providing the community's demands ${ }^{(5)}$.

This paper aims to examine and analyze the government's strategy in maintaining and managing water resources in ensuring the availability of clean water in Indonesia considering that Indonesia has abundant water resources compared to several other countries. To address some of the problems, this paper reviewed philosophically and conceptually by combining the perspectives of practical steps at the basic level such as strategies in the form of policies that have been made such as regulation, management (in management, the extent of human/government intervention in maintaining the health of environmental ecosystems, including water sources and the extent to which they are used, then what methods are used and agreed upon by stakeholders in ensuring that water needs can be met), evaluation, and efforts to maintain/protect water sources. Maintaining the availability of clean water is one of the globally agreed Sustainable Development Goals (SDGs). This goal is motivated by the depletion of water supplies and the availability of clean water in the world caused by global warmings, such as climate change which affects the availability of clean water. Various parts of the world, including Indonesia, are affected by climate change. The impact of climate change varies, depending on the location. Climate change caused by global warming has resulted in an unstable atmosphere in the lower layers, especially those close to the earth's surface.

Global warming is indicated by an increase in the earth's temperature that lasts for a decade, including climate change. According to Burke (2018), the climate is the average weather which also serves as a marker of the state of the atmosphere over a certain period. ${ }^{(6)}$ Climate changes continuously as a result of the interaction of a component with external factors such as volcanic eruptions, variations in sunlight, and human-caused factors such as changes in land use and the usage of fossil fuels. Similar statements were conveyed by Yoro (2020) that the primary cause of this warming is the burning of fossil fuels, such as coal, oil, and natural gas, which releases carbon dioxide and other gases known as greenhouse gases (GHG) into the atmosphere ${ }^{(7)}$. According to Kraaijenbrink (2017), following the Industrial Revolution, the average surface temperature of the Earth had increased by $1{ }^{\circ} \mathrm{C}{ }^{(8)}$. Figure 1 depicts the worldwide temperature projection.

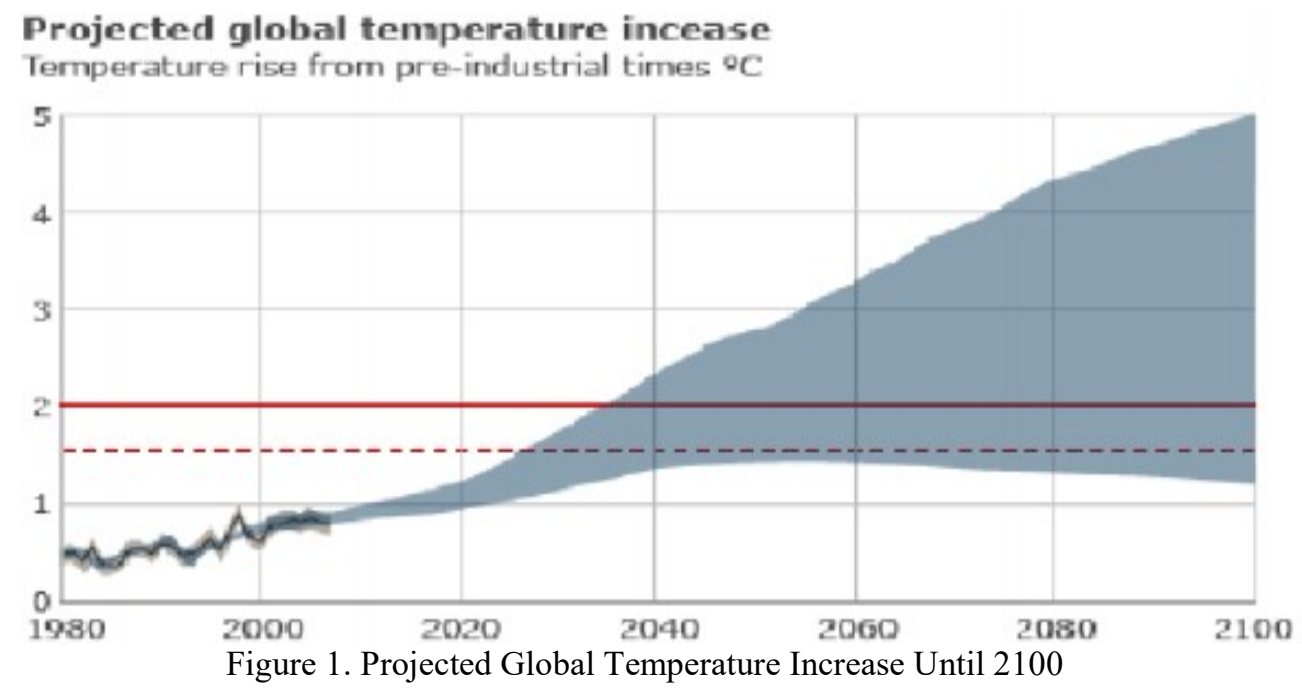

The 2007 IPCC report stated that climate change is characterized by changes in the Earth's surface temperature, rainfall, extreme weather events, ice/snow cover, and sea level. Causes of climate change include the Greenhouse Effect, Increased Global Warming Emissions, and Changes in Earth's Orbit. The global 21st-century surface temperature rise on all models is projected to rise by $1.8^{0} \mathrm{C}$ to $4^{0} \mathrm{C}$. The availability of freshwater is expected to decline along with population growth and the increase in water demand is expected to rise further, affecting millions more people by 2050. (IPCC, 2007). As stated by Sarkar (2019), climate change has a serious impact on life on earth where weather patterns are an 
important part of life, affecting various activities and human health ${ }^{(9)}$. As a result, climate change will have a significant impact on life on Earth. One of the negative consequences is a reduction in the amount of water quantity. Global warming triggers an increase in the amount of water in the atmosphere, which causes more rain to fall. According to Wagner ${ }^{(5)}$, extreme rainfall results in a high possibility of water returning directly to the sea, with no time to store it in clean water sources for human consumption ${ }^{(10,11)}$. An increase in rainfall can increase the quantity of clean water sources, but it will also reduce the quality of clean water. This is due to the fact that heavy rainfall reduces the quality of water sources. Furthermore, the increases in temperature also cause the chlorine level in clean water to increase. One of the issues affecting human needs as a result of global warming is the availability of water ${ }^{(12)(13)(14)}$. Water availability is a crucial issue related to climate change ${ }^{(15)}$. Water is impacted by climate change. Water availability has a significant impact on human life; in fact, water can be one of the impediments to a country's economic growth ${ }^{(16)}$.

Based on literature studies that have been carried out, it was found that the groundwater balance is influenced by water availability, rainfall, precipitation, and evapotranspiration. Therefore, rainfall data is needed as a supporting factor (17). Water is a basic need for every living being on Earth. Humans rely on water not only to meet domestic household needs but also for production, industrial, and other needs ${ }^{(18)}$. Some areas are threatened by a lack of clean water. If the vulnerability of clean water is not immediately addressed, then the problem will escalate into a disaster. According to Edalatpour (2018), people must adopt self-defense actions through adaptation $(19,20)$. According to Romano (2018), everyone will adapt based on their different adaptive abilities ${ }^{(21,22)}$. If the adaptive abilities are excellent, the self-defense against changing situations will be better. Coastal communities adapt because of flooding, while mountain villages adapt because rivers are a source of dirty water. Various studies have discussed the effect of climate change on rainfall, which affects the quality/quantity of clean water, which is also considered a component of water availability.

WWF (World Wide Fund) revealed in 2012 that over the last century, the annual mean temperature climbed by $0.72-3.92^{\circ} \mathrm{C}$, but rainfall decreased by 2 $3 \%$ (23). The southern part of Indonesia has experienced a one-month delay in the rainy season, with an increase in rainfall intensity of up to $10 \%$ during the rainy season and a $75 \%$ decrease during the dry season (24). The findings of Agustini's (2021) research on the effect of climate change on the availability of raw water in Greater Malang and analysis of trends in surface water volume changes from 2003 to $2012^{(25)}$, provide an estimate of surface water volume in Malang City over the next two decades. The volume of surface water increases by $19 \%$ in the tenth year, $28.5 \%$ in the fifteenth year, and $39 \%$ in the twentieth year. If this surface water can be used as a source of raw water, an additional 2000 million $\mathrm{m}^{3}$ of raw water will be available by 2034 . According to research conducted by Amalia in 2014 on the availability of safe drinking water and climate change, a case study of the water crisis in Kedungkarang, In Demak Regency, the well water discharge in the 1990s dries faster than it does in the 2010 s $^{(26)}$. The expense of acquiring safe drinking water rises as a result. Due to the increase in air temperature, shallow groundwater/well water evaporates faster through the process of evaporation and evapotranspiration. The water crisis is caused by the unpredictability of the seasons. As shown by a previous study ${ }^{(27)}$, water availability becomes a threat in dry subtropical and tropical areas, with predictions of up to a $10-30 \%$ water scarcity which can trigger drought disasters so that the impact on the water sector, which is influenced by climate change, might disrupt human social life. A previous study (28) revealed that human social life is one of the causes of water depletion in Indonesia. Previous research (28) demonstrates how human activities influence water supply.

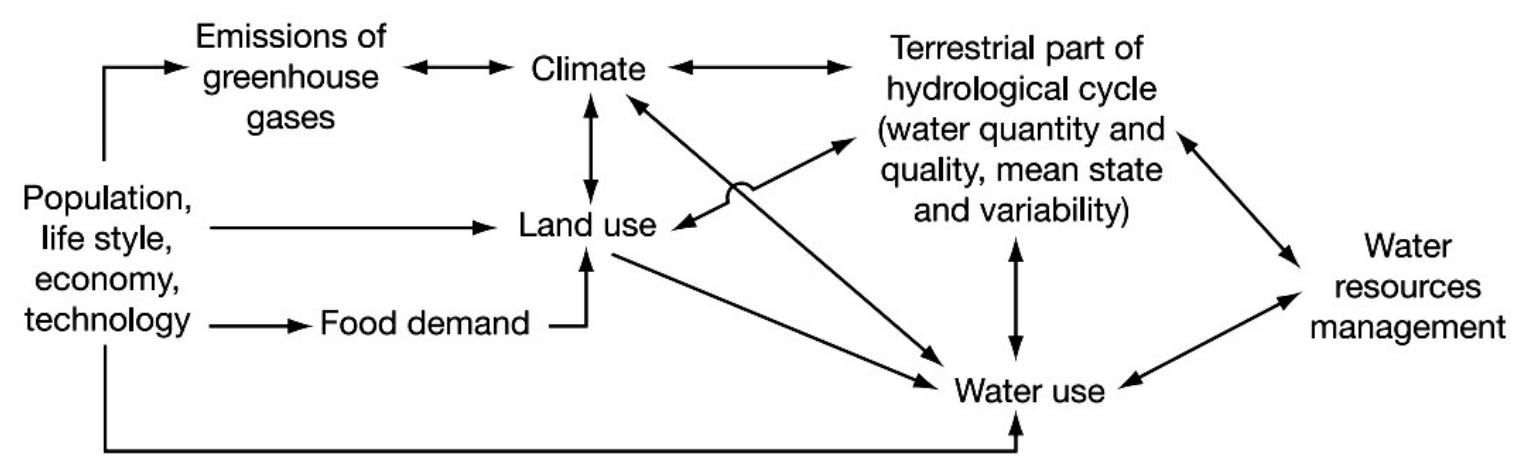

Figure 4 Human Needs in Meeting Water Demands 
Human activities have an impact on the amount and quality of water resources, as well as their management. Significant changes in water consumption or the hydrological cycle necessitate adaptation in water resource management, requiring the government to take preventive actions in order to sustain water availability in Indonesia.

\section{MATERIAL AND METHODS}

This paper used a qualitative descriptive method with a literature study approach ${ }^{(29)}$. This qualitative research method is used to explore and understand a central phenomenon ${ }^{(30)}$. This paper was interesting to study because climate change events can also increase the water crisis. The choice of subject in this paper was based on the water crisis caused by the unstable change of seasons. This is also based on global warming which is the background of climate change and its impact on water availability. The data used in this paper was sourced from secondary data. Secondary data is collected from other sources which can be in the form of readings or literature and various other data sources ${ }^{(30)}$. Secondary data in this paper was sourced from publications of journals and research results and other manuscripts related to this paper, as well as online media. The stage of selecting the review literature began with the process of selecting articles and understanding all related articles with the same subject. Following this, the discussion was divided by taking a common thread which was then developed into a new section. Data were analyzed using the steps or analysis model by Miles and Huberman of triangulation model. According to Sari (2020), literature studies can be analyzed using a triangulation model, including reducing data, summarizing, choosing the main aspects, and focusing on significant things obtained from the literature study (31). The data were summarized and selected so that they would provide a clear picture. Furthermore, data presentation was carried out in the form of brief descriptions, charts, relationships between categories, and the like. However, in this paper, the data was presented in the form of narrative text. The last stage was drawing conclusions and verification, followed by drawing conclusions from the data that has been written.

\section{RESULTS AND DISCUSSION}

In seeking the availability of water in the present and future, the government takes several preventive steps such as carrying out management, protection in the form of policies that protect the availability of water and its use, and evaluation.

\section{Water Resources Management.}

One of the causes of the water crisis is the weakness of the implementation of water management. Management in a broad sense is an activity that includes inventory, regulation of utilization, licensing, control, and supervision in the context of groundwater conservation. Integrated management of water resources can be performed by prioritizing utilization ${ }^{(16)}$, planning appropriate water allocation, conducting water conservation sustainably (15), and reducing the likelihood of contamination, among other water resource management actions ${ }^{(28)}$. Water is one of the natural resources that must be preserved for the needs of life today and in the future. According to a previous study ${ }^{(32)}$, water is an essential need in human life which is a natural resource that its availability must be maintained ${ }^{(33)}$. The vulnerability of the availability and quality of clean water has now become one of the major issues faced by several local governments in Indonesia. According to a prior study ${ }^{(33)}$, the main cause of this problem is a rapid change in land use, which results in less infiltration and more run-off. Furthermore, the issue of quantity and quality degradation is critical in the context of optimal water use. The findings of monitoring conducted by 30 Provincial Bapedalda on 35 rivers in Indonesia suggest that the overall state of water quality is polluted. Figure 3 shows the 2020 Water Quality Index in Indonesia's 563 provinces, according to the Ministry of Environment.

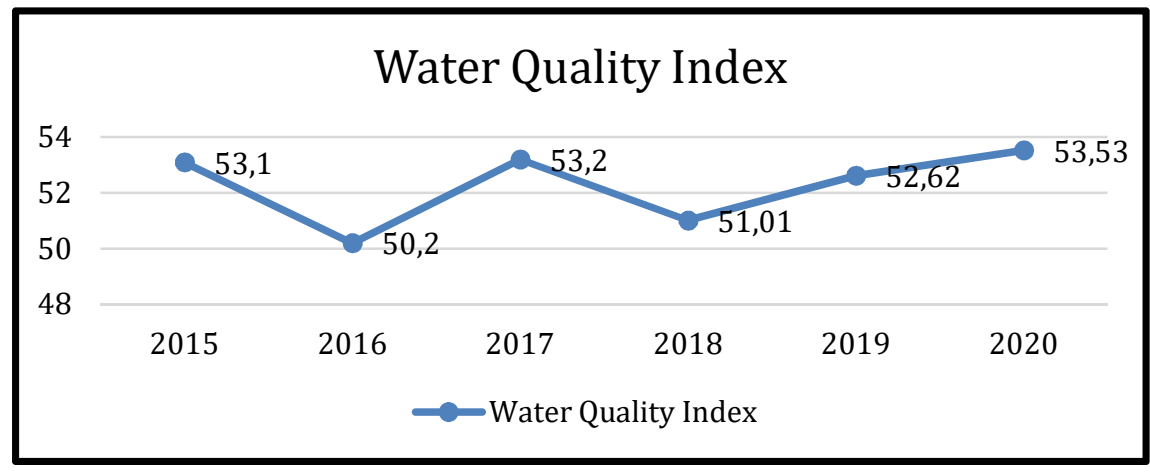

Figure 3. Water Quality Index

Source: Ministry of Environment, 2020 
The figure above demonstrates the results of monitoring of 563 points, 80 rivers, and 563 provinces based on several parameters in physics including Dissolved Oxygen, Power of Hydrogen, Total Suspended Ecological Oxygen Demand, Chemical Oxygen Demand, Total Phosphate, Nitrate, and Focal Coliform. The Water Quality Index was recorded from 2015 to 2018 which indicated that the value of the water quality index in Indonesia had fluctuated.
Then, from 2018 to 2020 , water quality has increased to 53.53. It indicates that there was an improvement in 2020. Currently, water sources that can be utilized by humans are increasingly compliant ${ }^{(34)}$. The increase in population is directly proportional to the increase in water demand ${ }^{(35)}$. The narrowing of water sources in the form of rivers in Indonesia can be seen in the picture below.

\begin{tabular}{|c|c|c|c|c|c|c|c|}
\hline $\mathrm{ma}$ & Aovint & 2018 & 20,10 & 2017 & 2018 & 2010 & 2020 \\
\hline 1 & Aceh & 71,32 & 70,36 & 80,00 & 75,71 & 60.56 & 61,43 \\
\hline 2 & Sumatera Utara & 76,00 & 75,43 & 78,33 & 63,06 & 51.11 & 53,33 \\
\hline 3 & Rau & 46,39 & 50,75 & 65,23 & 73,68 & 53.55 & 53,24 \\
\hline 4 & Kepulasan Fias & 84,67 & 80,00 & 66,67 & 57,85 & 54,00 & 50,00 \\
\hline 5 & Jambi & 57,50 & 61,00 & 57,50 & 81,21 & 58.49 & 56,75 \\
\hline 6 & Bengerula & 88,33 & 80,97 & 80,80 & 82,08 & 47,64 & 50,83 \\
\hline 7 & Sumatera Barat & 31,04 & 40,00 & 64,56 & 83,98 & 53.19 & 53,50 \\
\hline 8 & Sumatera Selatan & 88,67 & 84,05 & 77,62 & 88,15 & 64,45 & 63,33 \\
\hline 9 & Bangea Beitung & 81,67 & 82,08 & 72,50 & 82,13 & 62.29 & 65,63 \\
\hline 10 & Lampung & 71,85 & 68,10 & 55,56 & 68,73 & 55,74 & 56,21 \\
\hline 11 & Banten & 72,75 & 80,00 & 35,98 & 67,32 & 43.11 & 50,56 \\
\hline 12 & DN Jakarta & 22,35 & 24,62 & 21,33 & 51,93 & 41.94 & 42,73 \\
\hline 13 & Jawa Barat & 75,30 & 32,86 & 29,00 & 65,77 & 45.59 & 41,50 \\
\hline 14 & Jawa Tengah & 47,45 & 46,73 & 45,43 & 77,77 & 51,64 & 55,21 \\
\hline 15 & DI Yoggakarta & 21,84 & 26,97 & 20,19 & 81,63 & 35.37 & 50,00 \\
\hline 16 & Jawa Timur & 48,25 & 40,08 & 37,08 & 74,43 & 50,79 & 53,85 \\
\hline 17 & Bali & 87,67 & 89,09 & 79,50 & 77,67 & 65,33 & 64,33 \\
\hline 18 & Nusa Tenggara Barat & 23,59 & 27,19 & 79,50 & 74,63 & 40.23 & 50,98 \\
\hline 19 & Nusa Tenggara Timur & 55,19 & 35,18 & 39,63 & 58,09 & 59,48 & 59,19 \\
\hline 20 & Kalimantan Barat & 82,33 & 80,80 & 80,00 & 69,38 & 50,00 & 51,67 \\
\hline 21 & Kalimantan Selatan & 36,00 & 43,78 & 73,57 & 75,80 & 55.31 & 51,67 \\
\hline 22 & Kalimantan Tengah & 70,89 & 82,22 & 62,35 & 61,15 & 56.80 & 53,61 \\
\hline 23 & Kalimantan Timur & \multirow{2}{*}{77,90} & \multirow{2}{*}{79,77} & 73,33 & 86,19 & 62.01 & 60,00 \\
\hline 24 & Kalimantan Utara & & & 72,96 & 81,86 & 52.22 & 51,82 \\
\hline 25 & Sulawes Selatan & 72,43 & 75,44 & 77,62 & 82,62 & 58,40 & 52,38 \\
\hline 26 & Sulawesi Tengara & 80,00 & 80,00 & 64,67 & 86,17 & 5055 & 51,60 \\
\hline 27 & Sulawes Tengah & 73,33 & 49,33 & 56,44 & 75,95 & 62.59 & 61,67 \\
\hline 28 & Sulawes Barat & 56,00 & 45,13 & 73.89 & 82,43 & 56.15 & 52,44 \\
\hline 29 & Gorontalo & 49,67 & 52,62 & 40,00 & 81,93 & 57,20 & 53,00 \\
\hline 30 & Sulawes: Utara & 50,46 & 59,62 & 57,69 & 78,50 & 45,48 & 50,53 \\
\hline 31 & Maluku & 78,61 & 58,81 & 71,33 & 67,40 & 57,56 & 55,67 \\
\hline 32 & Malcku Utara & 65,19 & 64,62 & 63,64 & 88,01 & 53,61 & 50,00 \\
\hline 33 & Papas Barat & 76,67 & 76,67 & 82,50 & 81,25 & 53.89 & 52,22 \\
\hline 34 & Papaa & 80,00 & $76, \infty 0$ & 77,33 & 61,78 & 47,29 & 55,00 \\
\hline
\end{tabular}

Figure 4 River Narrowing in Indonesia

Source: Ministry of Environment (2020)

Every region in Indonesia has a river as a water source. The table above shows that from 2015 to 2021, the water source has experienced a narrowing. This indicates that the availability of water in Indonesia is running low. The hydrology of the water cycle is fixed so that the role or strategy of the government is required to maintain the availability and quality of water in Indonesia. Therefore, the government is expected to have a strategy so that water needs and availability for life today and in the future can be fulfilled. The strategy carried out by the government can be seen from several aspects, including Management. One of the ways to maintain water availability is through water resource management. In summary, water resource management can be seen in Figure 5 as follows. 


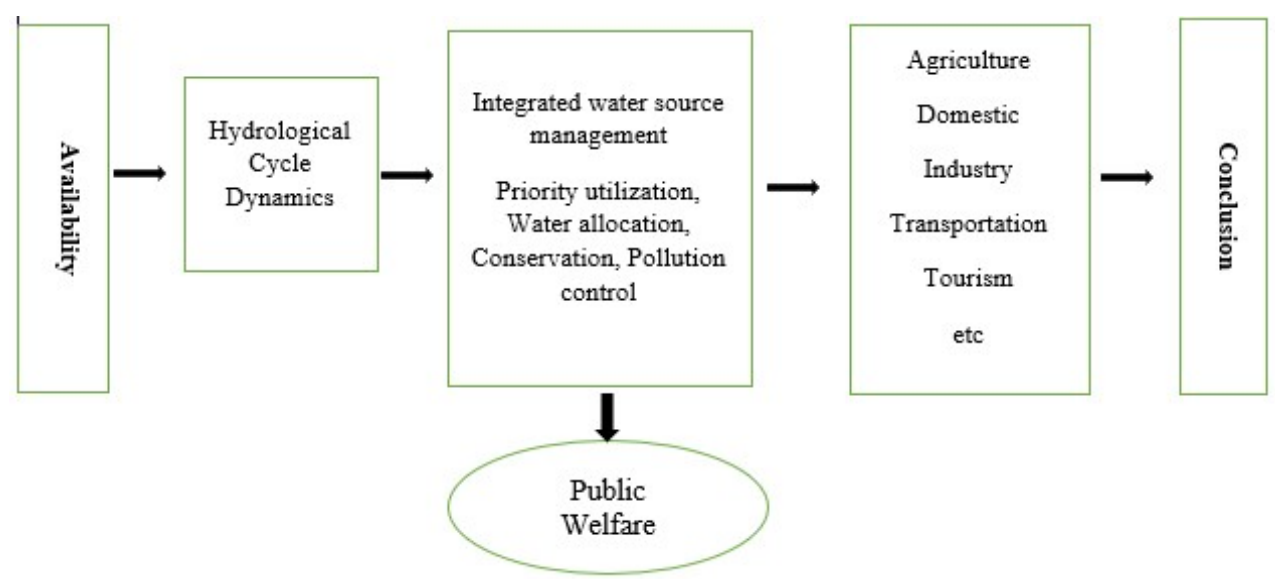

Figure 5. Integrated management of water resources

Water resource management encompasses both quantitative and qualitative aspects of water management. Surface and groundwater resource management must be focused effectively and efficiently by prioritizing demand/utilization, adequate water allocation, and water conservation implementation ${ }^{(17)}$. The increased usage of water, combined with the existing conditions following the COVID-19 pandemic, has increased the use of water in carrying out health protocols. As a result, it is essential to regulate its use proportionally ${ }^{(10)}$. The Ministry of Environment in its implementation has carried out quantitative and qualitative management of water availability by taking into consideration and determining priority programs and activities in water utilization. This is accomplished by regularly monitoring river water both manually and automatically. Manual monitoring can be carried out in multiple locations, while automatic monitoring is carried out continuously, momentarily, and there are more data obtained in one monitoring point (Ministry of the Environment, 2020). The next effort in management is environmentally friendly management, which includes the implementation of water conservation. Many conservation actions are now being conducted by various parties (private). This of course aims to meet the water needs of the community. However, in reality, although conservation has involved the private sector, the target has not yet reached the target. This is demonstrated by the presence of several areas where access to water is still challenging. The following is the location of the distribution of marine and water conservation in Indonesia.

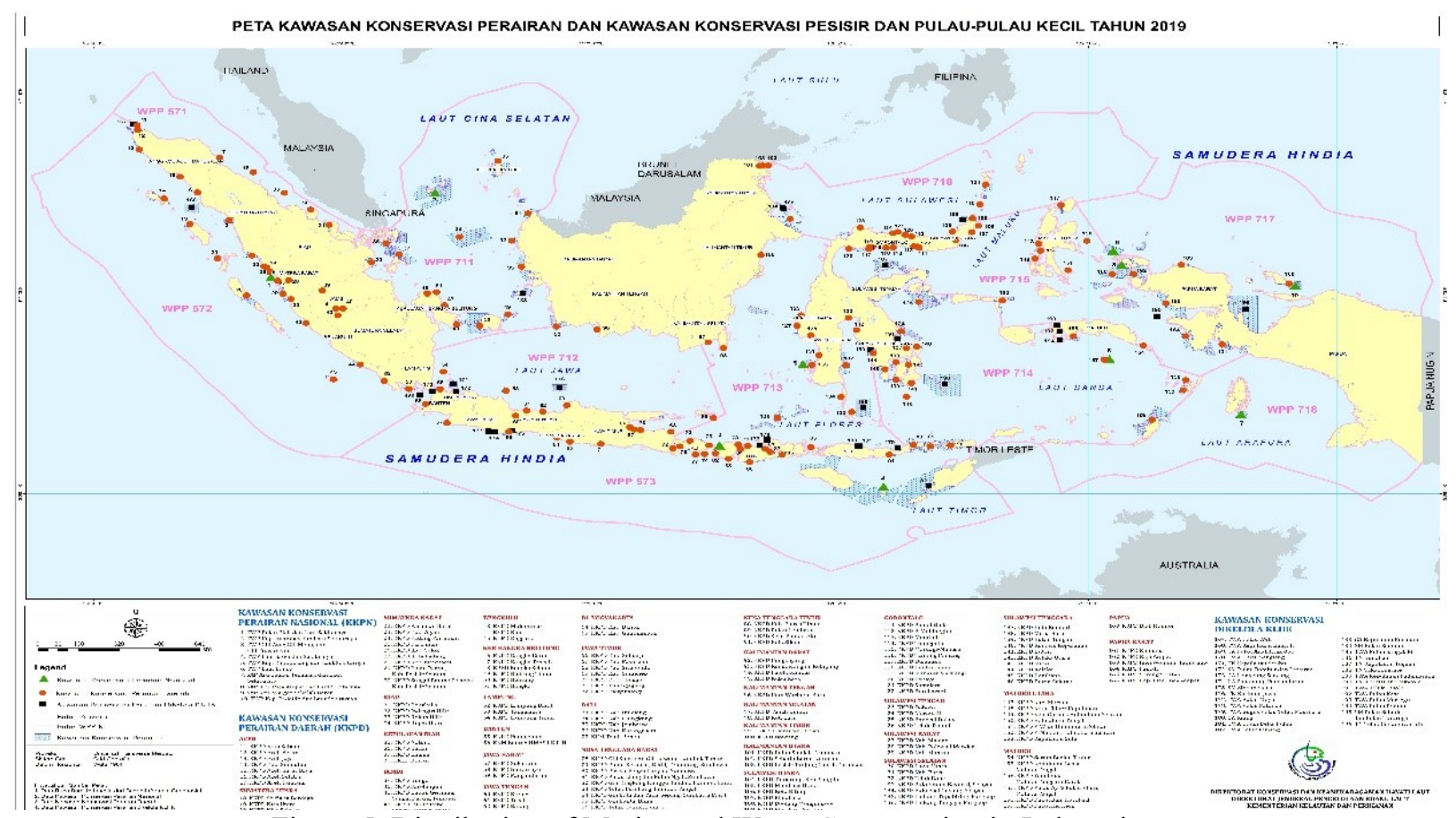

Figure 5. Distribution of Marine and Water Conservation in Indonesia

Source: Directorate General of Marine Spatial Management, 2019 
The map above demonstrates that the conservation efforts in Indonesian waterways are divided into two categories. Some of the Indonesian seas with a green triangle symbol $(\underline{C})$ are National Water Conservation Areas (Pieh Island and the surrounding sea, Anambas Islands and the surrounding seas, Gili Anyar, Gili Meno and Gili Trawangan, Sawu Sea and its surroundings, Kepapang islands, and surrounding seas, Raja Ampat Islands). and the surrounding seas, the western Weigo Islands, the Pedido islands and the surrounding seas. Meanwhile, the red dot symbol ( $($ ) represents the Regional Waters Conservation Area (KKPD) which each province manages and controls. Conservation is practiced in Indonesia, but only to a limited extent. This is demonstrated by the fact that some communities in some locations have not fully secured the right to utilize water availability, and some of the poor have trouble obtaining access to a clean water supply to meet their fundamental needs.

\section{Protection of Water Resources}

Protection encompasses activities or actions that actively promote the success of the regulation (Policy) and how the policy's implementation can have a positive impact on the surrounding environment. Water resource management entails various parties and must be carried out properly with legal and technical advice. There are numerous technical and non-technical issues and barriers to the implementation of water management in Indonesia. The challenge of groundwater management is also prompted by a paradigm shift, which influences the formulation of policies and practices for water management and availability. At this time, management issues such as altering the government's function from provider to enabler and decentralized governance systems frequently give rise to local authorities. Furthermore, changes in management patterns, such as the shift from government to privatepublic participation, cause issues. Regulations issued by the government in the form of policies are legal institutions that act and become the spearhead in the implementation of water resource management.

Law No. 17 of 2019 concerning Water Resources is a policy that strictly regulates water resources in Indonesia. The Government has formulated and established various policies in the groundwater sector as follows:

a. Organizing groundwater management according to the principles of conservation, public benefit, affordability, justice, balance, independence, local wisdom, environmental insight, sustainability, continuity, integration and harmony, transparency, and accountability. Some of the provisions imposed are the obligation to perform conservation efforts for people who utilize groundwater, as well as other activities with the potential to damage the groundwater environmental conditions, such as mining activities, groundwater drainage, construction of residential areas, industrial areas, and others.

b. Perform groundwater management (in article 21). Water Resources Management Activities include Water Resources Conservation, Water Resources Utilization, and Water Damage Control.

c. Utilization of Water Resources is intended to utilize Water Resources sustainably with the main priority to fulfill water for the daily fundamental needs of the community.

d. Water Resources Management is performed through coordination by integrating the interests of various sectors, regions, and stakeholders in the field of Water Resources.

A law has been enacted to control both technical and non-technical water resource management. However, the aim for implementing groundwater management is still not optimal. The fact that groundwater management has not been done wisely and extensively demonstrates this. There are still some aspects that have not been guaranteed in integrated and sustainable management; for instance, the abundance of water that causes flooding during the rainy season demonstrates the lack of a sustainable approach because there is no balance of Economic, Social, and Environmental in management implementation. Policies do not guarantee various issues, including every individual's right to clean water, including groundwater, to meet their daily needs, as well as the community's fundamental right to obtain access to groundwater supplies to meet a variety of needs. Groundwater management coordination is carried out between government industries and/or regional governments in order to optimize groundwater protection implementation. The following are some of the issues generated by the government's lack of cooperation and supervision: Groundwater management by local governments that is not based on transboundary groundwater basins but rather on administrative boundaries. This clearly contradicts the fundamental character of groundwater, which flows according to its hydrogeological conditions without regard for administrative boundaries. Between collecting agencies or groundwater data managers, there is no integrated groundwater data and information network. This is due to a lack of rigid compliance with regulations and a lack of human resources in the regions. Conflicts of interest arise between consumers of raw water sources as a result of the rising degradation of quality, quantity, and groundwater environment, particularly in urban groundwater basins. On the other hand, in line with the dynamics of regional growth, there is a very rapid increase in the demand for raw water supplies. Due to a lack of resources (people, equipment, and costs) at both the central and local government levels, groundwater management 
implementation has been less successful and less than optimal.

\section{Evaluation and Monitoring of Water Management}

The implementation of conservation and control efforts must be based on the results of a Groundwater Hazard And Risk Assessment. According to Wicaksono (2019), within the framework of groundwater conservation, hazard and risk assessments are based on two aspects, including natural and anthropogenic hazards/risks that can cause changes in groundwater potential both in quantity and quality and natural and anthropogenic hazards/risks that can cause changes on the allocation of groundwater resources (36). The hazard and risk assessment within the framework of groundwater control is based on three things: the hazard/risk of the impact of groundwater extraction activities from human activities, the hazard/risk of groundwater contamination naturally and as a result of human activities, and the feasibility of recovering groundwater damage ${ }^{(37)}$. The assessment of hazards and dangers to groundwater must begin from the point of extraction, including the catchment region of groundwater and water distribution, and continue until the water is used by the community for various reasons.

Integrated groundwater conservation operations are one aspect of water resource management. The Water Resources Law, as outlined in Law No. 17 of 2019, reveals that groundwater conservation operations still require more comprehensive instructions in order to perform properly. In practice, water resource management and control in Indonesia are only concerned with restricting water use. There are a limited number of controls that lead to water quality management. Water quality control is not only concerned with water and soil, but also with environmental issues such as land use and waste disposal to ensure that it does not pollute the soil, which is also a determining factor in water quality. It is advised that the area points that have the potential to pollute groundwater be mapped in order to ease the monitoring and supervision of the implementation of controlling the quality and availability of water at various locations/areas.

In addition, a risk evaluation of water/groundwater sources is performed. In terms of quantity and quality, the risk assessment policy attempts to reduce the negative environmental impacts of using water/water sources so that water availability can occur constantly and sustainably. As a result, there is a balance between the use of water's economic value and its availability as part of the hydrological ecosystem, preventing the degradation of quantity, quality, and the environment. The risk assessment, on the other hand, does not appear to be as significant, as indicated by the lack of continuity in the implementation of management and use by both the community and the policies that govern it. This is undoubtedly a dilemma for the government as a policymaker, given the COVID-19 epidemic is currently the largest contributor to water use through 2021, as assessed by IWI. The COVID-19 policy demands people to follow health procedures, one of which is to wash their hands frequently and keep their surroundings clean. Of sure, it will be a popular activity for the time being. And the government should be able to effectively establish water management so that it can meet current water needs, particularly water needs during the COVID-19 era, as well as future needs.

\section{CONCLUSION}

One of the major issues faced by Indonesian local governments is the vulnerability of the availability and quality of clean water. In order to ensure water availability now and in the future, the government implements a number of preventive measures, such as management regulations, water availability and protection, and evaluation. Water management is done quantitatively and qualitatively by managing surface water resources and groundwater resources. In its execution, the Ministry of Environment has carried out both quantitative and qualitative control of water availability. The following effort will be in the management of environmentally sound management, which will involve the deployment of water conservation measures. Problems in the implementation of water management in Indonesia, both technically and non-technically, are also triggered by a lack of supervision in the implementation of the Law that regulates the paradigm shift, which then affects the policies and processes of water management and availability itself. Management issues include a shift in the government's role from provider to enabler, decentralized government systems that frequently lead to local authorities, changes in management patterns, and a shift from government participation to privatepublic partnerships. Groundwater management has not been done properly or extensively, and there is no long-term solution. Some things are still not assured in integrated and sustainable management. The application of groundwater management has become less effective and less than optimal due to limited resources (people, equipment, and cost). In terms of policy, groundwater conservation operations continue to require more comprehensive instructions in order to function properly. The hazard evaluation is based on two factors: natural and anthropogenic hazards/risks that induce changes in groundwater potential, both in quantity and quality, and are potentially dangerous. Air quality control is not only concerned with water and soil, but also with environmental issues such as land use and waste management so that it does not harm the soil. 


\section{REFERENCES}

1. Utama SYA, Inayati A, Sugiarto S. Hubungan Kondisi Jamban Keluarga Dan Sarana Air Bersih Dengan Kejadian Diare Pada Balita Di Wilayah Kerja Puskesmas Arosbaya Bangkalan. Din Kesehat J Kebidanan Dan Keperawatan. 2019;10(2):820-32.

https://doi.org/10.33859/dksm.v10i2.465

2. Hernaningsih T, Yudo S. Alternatif Teknologi Pengolahan Air Untuk Memenuhi Kebutuhan Air Bersih Di Daerah Pemukiman Nelayan Studi Kasus Perencanaan Penyediaan Air Bersih Di Daerah Pedesaaan Nelayan Kab. Pasir, Kalimantan Timur. J Air Indones. 2018;3(1). https://doi.org/10.29122/jai.v3i1.2316

3. Tortajada C. COVID-19 and clean water, sanitation and wastewater management. Int $\mathrm{J}$ Water Resour Dev [Internet]. 2021;37(2):17981. Available from: https://doi.org/10.1080/07900627.2021.1877956

4. D'Odorico P, Carr J, Dalin C, Dell'Angelo J, Konar M, Laio F, et al. Global virtual water trade and the hydrological cycle: patterns, drivers, and socio-environmental impacts. Environ Res Lett. 2019;14(5):53001. https://doi.org/10.1088/1748-9326/ab05f4

5. Wagner JT, Pramling Samuelsson I. WASH from the START: Water, Sanitation and Hygiene Education in Preschool. Int $\mathrm{J}$ Early Child [Internet]. 2019;51(1):5-21. Available from: https://doi.org/10.1007/s13158-019-00236-5

6. Burke M, González F, Baylis P, Heft-Neal S, Baysan C, Basu S, et al. Higher temperatures increase suicide rates in the United States and Mexico. Nat Clim Chang. 2018;8(8):723-9. https://doi.org/10.1038/s41558-018-0222-x

7. Yoro KO, Daramola MO. CO2 emission sources, greenhouse gases, and the global warming effect. In: Advances in carbon capture. Elsevier; $2020 . \quad$ p. $3-28$. https://doi.org/10.1016/B978-0-12-8196571.00001-3

8. Kraaijenbrink PDA, Bierkens MFP, Lutz AF, Immerzeel WW. Impact of a global temperature rise of 1.5 degrees Celsius on Asia's glaciers. Nature. 2017;549(7671):257-60. https://doi.org/10.1038/nature23878

9. Sarkar S, Chauhan A, Kumar R, Singh RP. Impact of deadly dust storms (May 2018) on air quality, meteorological, and atmospheric parameters over the northern parts of India. GeoHealth. 2019;3(3):67-80. https://doi.org/10.1029/2018GH000170

10. Fadhlurrohman MI, Purnomo EP, Khairina E, Fathani AT, Salsabila L, Fadhlurrohman MI, et al. Bibliometrics: Sustainable Clean Water Development And Sanitation Indonesia. J Qual Inq. 2021;12(3):2159-75.

11. Alim MA, Rahman A, Tao Z, Samali B, Khan MM, Shirin S. Suitability of roof harvested rainwater for potential potable water production: A scoping review. J Clean Prod. 2020;248:119226.

https://doi.org/10.1016/j.jclepro.2019.119226

12. Chowdhary P, Bharagava RN, Mishra S, Khan $\mathrm{N}$. Role of industries in water scarcity and its adverse effects on environment and human health. In: Environmental Concerns and Sustainable Development. Springer; 2020. p. 235-56. https://doi.org/10.1007/978-981-135889-0 12

13. Nugroho S. Analisis Iklim Ekstrim Untuk Deteksi Perubahan Iklim Di Sumatera Barat. J Ilmu Lingkung. 2019;17(1):7. https://doi.org/10.14710/jil.17.1.7-14

14. Ali R, Kuriqi A, Kisi O. Human-environment natural disasters interconnection in China: a review. Climate. 2020;8(4):48. https://doi.org/10.3390/cli8040048

15. Flörke M, Schneider C, McDonald RI. Water competition between cities and agriculture driven by climate change and urban growth. Nat Sustain. 2018;1(1):51-8. https://doi.org/10.1038/s41893-017-0006-8

16. Susilawaty A, Amansyah M, Nildawati. Kerentanan Ketersediaan Air Bersih Di Daerah Pesisir Dan Pulau - Pulau Kecil Sulawesi Selatan Indonesia. Al-sihahPublic Heal Sci J. 2016;8(2):194-203.

17. Rukundo E, Doğan A. Dominant influencing factors of groundwater recharge spatial patterns in Ergene river catchment, Turkey. Water. 2019;11(4):653.

https://doi.org/10.3390/w11040653

18. Gude VG. Desalination and water reuse to address global water scarcity. Rev Environ Sci Bio/Technology. 2017;16(4):591-609. https://doi.org/10.1007/s11157-017-9449-7

19. Edalatpour M, Liu L, Jacobi AM, Eid KF, Sommers AD. Managing water on heat transfer surfaces: A critical review of techniques to modify surface wettability for applications with condensation or evaporation. Appl Energy. 2018;222:967-92.

https://doi.org/10.1016/j.apenergy.2018.03.178

20. Hollander JA, Cunningham J. Empowerment self-defense training in a community population. Psychol Women Q. 2020;44(2):187-202. https://doi.org/10.1177/0361684319897937

21. Romano N, Nasta P, Bogena H, De Vita P, Stellato L, Vereecken H. Monitoring hydrological processes for land and water resources management in a Mediterranean ecosystem: The Alento River Catchment Observatory. Vadose Zo J. 2018;17(1):1-12. https://doi.org/10.2136/vzj2018.03.0042

22. Wang F, Zhang H, Li K, Lin Z, Yang J, Shen XL. A hybrid particle swarm optimization algorithm using adaptive learning strategy. Inf Sci (Ny). 2018;436:162-77. 
https://doi.org/10.1016/j.ins.2018.01.027

23. Selz V. Controls on Polar Ice Algal Communities and Their Coupling to Spring Phytoplankton Communities. Stanford University; 2018.

24. Allen K, Dupuy JM, Gei MG, Hulshof C, Medvigy D, Pizano C, et al. Will seasonally dry tropical forests be sensitive or resistant to future changes in rainfall regimes? Environ Res Lett. 2017;12(2):23001. https://doi.org/10.1088/17489326/aa5968

25. Agustini DT. Adaptation Strategies of Smallholder Farmers using Climate-Smart Agriculture: the case of Rejosari Village, Indonesia. University of Twente; 2021.

26. Parkinson S, Krey V, Huppmann D, Kahil T, McCollum D, Fricko O, et al. Balancing clean water-climate change mitigation trade-offs. Environ Res Lett. 2019;14(1):14009. https://doi.org/10.1088/1748-9326/aaf2a3

27. Zhan S, Song C, Wang J, Sheng Y, Quan J. A global assessment of terrestrial evapotranspiration increase due to surface water area change. Earth's Futur. 2019;7(3):266-82. https://doi.org/10.1029/2018EF001066

28. Yin B, Guan D, Zhou L, Zhou J, He X. Sensitivity assessment and simulation of water resource security in karst areas within the context of hydroclimate change. J Clean Prod. 2020;258:120994.

https://doi.org/10.1016/j.jclepro.2020.120994

29. Haradhan M. Qualitative Research Methodology in Social Sciences and Related Subjects. J Econ Dev Environ People. 2018;7(1):23-48. https://doi.org/10.26458/jedep.v7i1.571

30. Ruggiano N, Perry TE. Conducting secondary analysis of qualitative data: Should we, can we, and how? Qual Soc Work. 2019;18(1):81-97. https://doi.org/10.1177/1473325017700701

31. Sari M\& A. Penelitian Kepustakaan (Library
Research) dalam Penelitian Pendidikan IPA. Nat Cience J Penelit Bid IPA dan Pendidik IPA [Internet]. 2020;6(1):41-53. Available from: https://ejournal.uinib.ac.id/jurnal/index.php/natur alscience/article/view/1555/1159

32. Prein AF, Heymsfield AJ. Increased melting level height impacts surface precipitation phase and intensity. Nat Clim Chang. 2020;10(8):7716. https://doi.org/10.1038/s41558-020-0825-x

33. Jovovic R, Draskovic M, Delibasic M, Jovovic M. The concept of sustainable regional development-institutional aspects, policies and prospects. J Int Stud. 2017;10(1). https://doi.org/10.14254/2071-8330.2017/10$1 / 18$

34. Brander M, Davis G. Greenhouse gases, $\mathrm{CO} 2$, $\mathrm{CO} 2 \mathrm{e}$, and carbon: What do all these terms mean. Econom White Pap. 2012; https://doi.org/10.1002/ghg.1279

35. Goss M, Swain DL, Abatzoglou JT, Sarhadi A, Kolden CA, Williams AP, et al. Climate change is increasing the likelihood of extreme autumn wildfire conditions across California. Environ Res Lett. 2020;15(9):94016. https://doi.org/10.1088/1748-9326/ab83a7

36. Wicaksono AR, Putranto TT, Setyawan R. Pemodelan Hidrogeologi Cekungan Airtanah Samarinda-Bontang Segmen Penajam Dalam Upaya Konservasi Airtanah Berbasis Cekungan, Kabupaten Penajam Paser Utara, Provinsi Kalimantan Timur. J Geosains dan Teknol. 2019;2(1):13-23. https://doi.org/10.14710/jgt.2.1.2019.13-23

37. Purwoarminta A, Lubis RF, Maria R. Imbuhan Airtanah Buatan untuk Konservasi Cekungan Airtanah Bandung-Soreang. Ris Geol dan Pertamb. 2019;29(1):65-73. https://doi.org/10.14203/risetgeotam2019.v29.10 04. 